\title{
Teori Pendidikan Keluarga dan Tanggung Jawab Orang Tua dalam Pendidikan Anak Usia Dini
}

\author{
M. Syahran Jailani \\ IAIN Sulthan Thaha Saifuddin Jambi \\ E-mail: m.syahran@ymail.com
}

\begin{abstract}
This paper describes the responsibilities of parents in early childhood education. From the review of the literature it is known that the family environment becomes a major place of a child to education. Father and mother in the family becomes the first educators in the process of development of a child's life. Parents do not just build a relationship and do various family for reproductive purposes, continue descent, and establish affection. The main task of the family is to create buildings and atmosphere of family education process so that the next generation of intelligent and noble generation as a solid footing in the tread life and the journey of human children. The fact is supported by the findings of the theories that support the importance of family education as the first basic education of children.
\end{abstract}

Keywords: family, education, early children

\begin{abstract}
Abstrak
Makalah ini menjelaskan tanggung jawab orang tua dalam pendidikan anak usia dini. Dari kajian literatur diketahui bahwa lingkungan keluarga menjadi tempat yang utama seorang anak memperoleh pendidikan. Ayah dan ibu dalam keluarga menjadi pendidik pertama dalam proses perkembangan kehidupan anak. Orang tua tidak sekedar membangun silaturahmi dan melakukan berbagai tujuan berkeluarga untuk reproduksi, meneruskan keturunan, dan menjalin kasih sayang. Tugas utama keluarga adalah menciptakan bangunan dan suasana proses pendidikan keluarga sehingga melahirkan generasi yang cerdas dan berakhlak mulia sebagai pijakan yang kokoh dalam menapaki kehidupan dan perjalanan anak manusia. Kenyataan tersebut ditopang temuan teori-teori yang mendukung pentingnya pendidikan keluarga sebagai dasar pertama pendidikan anak-anak.
\end{abstract}

Kata Kunci: keluarga, pendidikan, anak usia dini. 


\section{A. Pendahuluan}

Keluarga sebagai sebuah lembaga pendidikan yang pertama dan utama. Keluarga diharapkan senantiasa berusaha menyediakan kebutuhan, baik biologis maupun psikologis bagi anak, serta merawat dan mendidiknya. Keluarga diharapkan mampu menghasilkan anak-anak yang dapat tumbuh menjadi pribadi, serta mampu hidup di tengah-tengah masyarakat. Sekaligus dapat menerima dan mewarisi nilai-nilai kehidupan dan kebudayaan. Menurut Selo Soemarjan, keluarga adalah sebagai kelompok inti, sebab keluarga adalah masyarakat pendidikan pertama dan bersifat alamiah. Dalam keluarga, anak dipersiapkan untuk menjalani tingkatan-tingkatan perkembangannya sebagai bekal ketika memasuki dunia orang dewasa, bahasa, adat istiadat dan seluruh isi kebudayaan, seharusnya menjadi tugas yang dikerjakan keluarga dan masyarakat di dalam mempertahankan kehidupan oleh keluarga. ${ }^{1}$

Dalam wahana keluarga, orang tua terutama ayah sebagai kepala keluarga dengan bantuan anggotanya harus mampu mempersiapkan segala sesuatu yang dibutuhkan sebuah keluarga. Seperti bimbingan, ajakan, pemberian contoh, kadang sanksi yang khas dalam sebuah keluarga, baik dalam wujud pekerjaan kerumahtanggaan, keagamaan maupun kemasyarakatan lainnya, yang dipikul atas seluruh anggota keluarga, atau secara individual, termasuk interaksi dalam pendidikan keluarga. Menurut Ki Hajar Dewantara, keluarga adalah kumpulan individu yang memiliki rasa pengabdian tanpa pamrih, demi kepentingan seluruh individu yang bernaung di dalamnya. Begitu pentingnya keluarga dari kehidupan manusia bagi individu maupun sekelompok orang. ${ }^{2}$

Anak tidak bisa dipisahkan dari keluarga, dengan keluarga orang dapat berkumpul, bertemu dan bersilaturahmi. Dapat dibayangkan jika manusia hidup tanpa keluarga. Tanpa disadari secara tidak langsung, telah menghilangkan fitrah seseorang sebagai makhluk sosial. Hal ini sejalan dengan pernyataan Selo Soemarjan, keluarga adalah sekelompok orang yang dipersatukan oleh pertalian kekeluargaan, perkawinan atau adopsi yang disetujui

1 Selo Soemarjan, Sosiologi Suatu Pengantar, (Yogyakarta: Gajah Mada Press, 1962), hlm. 127.

${ }^{2}$ Ki Hajar Dewantara, Ilmu Pendidikan, (Yogyakarta: Taman Siswa, 1961), hlm. 250. 
secara sosial dan pada umumnya sesuai dengan peranan-peranan sosial yang telah dirumuskan dengan baik. ${ }^{3}$

Abdullah dan Berns juga memperkuat agrumen, bahwa keluarga adalah suatu kelompok sosial yang ditandai oleh tempat tinggal bersama kerja sama ekonomi, dan reproduksi. ${ }^{4}$ Di sisi lain, dalam konteks pengertian psikologis, keluarga dimaknai sebagai kumpulan orang yang hidup bersama dengan tempat tinggal bersama dan masing-masing orang yang terlibat di dalamnya merasakan adanya pertautan batin sehingga terjadi saling memperhatikan, saling membantu, bersosial dan menyerahkan diri. $^{5}$

Begitu pula dalam kaitan pandangan pedagogis. Keluarga adalah satu persekutuan hidup yang dijalin oleh kasih sayang antara pasangan dua jenis manusia yang dikukuhkan dengan pernikahan dengan maksud untuk saling menyempurnakan. ${ }^{6}$

Selain itu, keluarga menjadi tempat untuk mendidik anak agar pandai, berpengalaman, berpengetahuan, dan berperilaku dengan baik. Kedua orang tua harus memahami dengan baik kewajiban dan tanggung jawab sebagai orang tua. Orang tua (ayah dan ibu) tidak hanya sekedar membangun silaturahmi dan melakukan berbagai tujuan berkeluarga, seperti reproduksi, meneruskan keturunan, menjalin kasih sayang dan lain sebagainya.

Tugas keluarga sangat urgen, yakni menciptakan suasana dalam keluarga proses pendidikan yang berkelanjutan (continues progress) guna melahirkan generasi penerus (keturunan) yang cerdas dan berakhlak (berbudi pekerti yang baik). Baik di mata orang tua, dan masyarakat.

Fondasi dan dasar-dasar yang kuat adalah awal pendidikan dalam keluarga, dasar kokoh dalam menapaki kehidupan yang lebih berat, dan luas bagi perjalanan anak-anak manusia berikutnya.

Sebagaimana yang telah digambarkan Allah swt. dalam kitab suci al-Qur'an, yang tertera pada Q.S. al-Nisā/4: 58; alTahrỉm/56: 6; Hūd/11: 46; al-Anfāl/8: 28; al-Kahfi/18: 48, di mana

${ }^{3}$ Soemarjan, Sosiologi Suatu Pengantar ..., hlm. 127.

4 M. Imron Abdullah, Pendidikan Keluarga Bagi Anak, (Cirebon: Lektur, 2003), hlm. 225.

${ }^{5}$ Robert M. Berns, Child, Family, School, Community Socilization and Support, (United State: Thomson Corporation, 2007), hlm. 87.

${ }^{6}$ Berns, Child, family ..., hlm. 88. 
ayat-ayat tersebut mengisyaratkan pentingnya mendidik anak dalam lingkup keluarga. ${ }^{7}$

\section{B. Pendidikan Keluarga: Nilai Pentingnya bagi Anak}

1. Pengertian Pendidikan Keluarga

Dalam berbagai literatur, para ahli memberikan berbagai sudut pandang tentang pengertian pendidikan keluarga. Misalnya Mansur, mendefinisikan pendidikan keluarga adalah proses pemberian nilai-nilai positif bagi tumbuh kembangnya anak sebagai fondasi pendidikan selanjutnya. ${ }^{8}$ Selain itu, Abdullah juga mendefinisikan pendidikan keluarga adalah segala usaha yang dilakukan oleh orang tua berupa pembiasaan dan improvisasi untuk membantu perkembangan pribadi anak. ${ }^{9}$ Pendapat lain yang dikemukakan oleh anNahlawi, Hasan Langgulung memberi batasan terhadap pengertian pendidikan keluarga sebagai usaha yang dilakukan oleh ayah dan ibu sebagai orang yang diberi tanggung jawab untuk memberikan nilai-nilai, akhlak, keteladanan dan kefitrahan. ${ }^{10}$

Ki Hajar Dewantara merupakan salah seorang tokoh pendidikan Indonesia, juga menyatakan bahwa alam keluarga bagi setiap orang (anak) adalah alam pendidikan permulaan. Untuk pertama kalinya, orang tua (ayah maupun ibu) berkedudukan sebagai penuntun (guru), sebagai pengajar, sebagai pendidik, pembimbing dan sebagai pendidik yang utama diperoleh anak. Maka tidak berlebihan kiranya manakala merujuk pada pendapat para ahli di atas konsep pendidikan keluarga. Tidak hanya sekedar tindakan (proses), tetapi ia hadir dalam praktek dan implementasi, yang dilaksanakan orang tua (ayah-ibu) degan nilai pendidikan pada keluarga. ${ }^{11}$

7 A. Soenarjo, Al-Qur'an dan Terjemahan Departemen Agama RI, (Jakarta: Teraju, 1989).

8 Mansur, Pendidikan Anak Usia Dini dalam Islam, (Yogyakarta: Pustaka Pelajar, 2005), hlm. 319.

${ }^{9}$ Abdullah, Pendidikan Keluarga ..., hlm. 232.

${ }^{10}$ Hasan Langgulung, Manusia dan Pendidikan, (Jakarta: Pustaka alHusna, 1986), hlm. 19.

${ }^{11}$ Dewantara, Ilmu Pendidikan, ..., hlm. 255. 
Perlu diketahui, mayoritas orang tua belum mengetahui bagaimana konsep pendidikan keluarga itu. Hal tersebut tanpa disadari para orang tua (ayah dan ibu) dalam praktek kesehariannya. Mereka telah menjalankan fungsi keluarga dalam pendidikan anak-anak. Pada hakikatnya, fungsi keluarga adalah sebagai pendidikan budi pekerti, sosial, kewarganegaraan, pembentukan kebiasaan dan pendidikan intelektual anak.

a. Mollehnhaur dalam Abdullah membagi tiga fungsi keluarga dalam pendidikan anak, yaitu:

b. Fungsi kuantitatif, yaitu menyediakan bagi pembentukan perilaku dasar, artinya keluarga tidak hanya menyediakan kebutuhan dasar fisik anak, berupa pakaian, makanan dan minuman, serta tempat tinggal yang layak. Akan tetapi, keluarga dituntut untuk menyediakan dan memfasilitasi ketersediaan dasar-dasar kebaikan, berupa perilaku, etika, sopan santun dan pembentukan karakter anak yang santun dan berakhlak baik sebagai fitrah manusia yang hakiki.

c. Fungsi-fungsi selektif, yaitu menyaring pengalaman anak dan ketidaksamaan posisi kemasyarakatan karena lingkungan belajar. Artinya pendidikan keluarga berfungsi sekaligus memerankan diri sebagai fungsi kontrol pengawasan terhadap diri anak akan berbagai informasi yang diterima anak. ${ }^{12}$ Terutama anak usia 00 tahun hingga 05 tahun yang belum memiliki pengetahuan dan pengalaman. Sehingga diharapkan mampu membedakan mana yang baik dan buruk. Oleh sebab itu, keluarga (ayah dan ibu) berkewajiban memberikan informasi dan pengalaman yang bermakna. Berupa pengalaman belajar secara langsung maupun tidak langsung, diharapkan pengalaman tersebut mampu diserap dan ditransformasi dalam diri anak.

d. Fungsi pedagogis, yaitu mewariskan nilai-nilai dan normanorma. Artinya pendidikan keluarga berfungsi memberikan warisan nilai-nilai yang berkaitan dengan aspek kepribadian anak. Tugas akhir pendidikan keluarga tercermin dari sikap, perilaku dan kepribadian

${ }^{12}$ Abdullah, Pendidikan Keluarga Bagi Anak, ..., hlm. 237. 
(personality) anak dalam kehidupan sehari-hari yang ditampilkan.

Sementara itu, ternyata fungsi keluarga bukan sebatas itu, misalnya Berns ${ }^{13}$, ia mengemukakan fungsi keluarga, yaitu: (a) fungsi reproduksi, (b) melaksanakan pendidikan dan sosialisasi di masyarakat, (c) membangun aturan-aturan sosial, (d) melakukan tindakan ekonomi, dan (e) membangun dan mendukung proses perkembangan emosi anak-anak.

2. Teori-teori Pendidikan Keluarga pada Anak Usia Dini

a. J.H. Pestolozzi (1746 - 1827).

Tokoh pendidikan lainnya yang juga telah meletakkan fondasi bagi pendidikan anak sejak dini adalah Johan Hendrik Pestolozzi. Ia dilahirkan di Zurich Swiss tahun 1746. Pada tahun 1774 ia memulai dengan mendirikan sekolah pertama yang disebut "Neuhof' di sebuah lahan pertanian miliknya. Di tempat tersebut ia mengembangkan ide-idenya dalam dunia pendidikan, di mana ide yang paling difokuskan adalah bagaimana mengintegrasikan pendidikan di kehidupan rumah tangga, pendidikan vokasional dan pendidikan membaca dan menulis.

Pestolozzi berpandangan bahwa pendidikan sebaiknya mengikuti sifat-sifat bawaan anak (child's nature). Dasar dari pendidikan ini menggunakan metode, yang merupakan perpaduan antara dunia alam terutama alam keluarga dan pendidikan yang praktis. Cara ialah membimbing anak dengan perlahan-lahan. Bisa dengan cara memulai usaha anak sendiri, yakni memberi kesempatan anak untuk berbuat dan melakukan sesuatu yang bermula dari "senseimpression" menuju ide-ide yang abstrak.

Pestolozzi yakin bahwa segala bentuk pendidikan adalah berdasarkan pengaruh dari pancaindera, dan melalui pengalaman serta potensi-potensi yang dimiliki untuk dikembangkan. Lingkungan rumah tangga dianggap sebagai pusat kegiatan bagi para ibu dalam mendidik anak, ibu mempunyai tanggung jawab yang terbesar dalam pendidikan anak. Maka Pestolozzi menganggap bahwa ibu adalah pahlawan dalam bidang pendidikan anak mereka.

${ }^{13}$ Berns, Child, family ..., hlm. 89-90. 
Ibu adalah orang yang mendorong anaknya untuk belajar sejak awal hidup anak. ${ }^{14}$

b. Friedrich Frobel ( $1782-1852)$

Ia lahir di kota Oberweisbach, Jerman pada tahun 1782. Frobel banyak belajar tentang konsep pendidikan dari pendahulunya, J.H. Pestolozzi yang dianggap olehnya sebagai "Bapak" pendidikan dan pembelajaran anak-anak. Pada tahun 1817 Frobel mendirikan perguruan di Kota Keilhau (Jerman) dengan memakai sistem dari Pestolozzi. Khusus untuk pendidikan anak-anak, Frobel mendirikan "Kindergarten" (taman kanak-kanak). Itulah sekolah pertama Frobel yang berdiri di kota Blanckenburg, Jerman. Selain ia mendirikan taman kanak-kanak (Kindergarten), juga mendirikan "taman ibu" (Frobel Kweekschool).

Di dalam pendidikan anak yang digagas Frobel, di antaranya bermainan, bernyanyi dan berbagai macam pekerjaan anak-anak yang diberikan, guna memberi pengalaman langsung kepada anak. Bagi Frobel, jika anakanak tidak bergerak dan lebih banyak diam, maka pertanda anak itu kurang sehat badan atau jiwanya. Bergeraknya anak-anak adalah akibat dari gerakan jiwanya, karena jiwa dan tubuh anak-anak bersifat satu. Gerakan badan akan mempengaruhi jiwa anak-anak untuk tumbuh kembang.

Konsep pendidikan Frobel ini pula yang mengilhami dirinya untuk menciptakan berbagai macam bentuk permainan, agar diharapkan mampu melahirkan anak-anak yang sehat, baik jasmani maupun rohani. Permainanpermainan yang digagas Frobel's School dapat dilakukan manakala dengan memperhatikan syarat-syarat sebagai berikut:

1) Permainan harus menyenangkan anak-anak,

2) Permainan harus memberi kesempatan pada anakanak untuk berfantasi,

3) Anak-anak harus cakap dan mampu menyelesaikan permainan,

4) Berilah pekerjaan permainan yang juga mengandung kesenian, dan

14 Soemiarti Patmonodewo, Pendidikan Anak Prasekolah, (Jakarta: Rineka Cipta, 2003), hlm. 5-6. 
5) Permainan diharapkan mengandung dan mengarahkan anak-anak ke arah ketertiban. Ketertiban tersebut dimaksudkan oleh Frobel untuk mendidik anak-anak "rasa kesusilaan", dan kelak diharapkan anak memiliki sikap kemasyarakatan dan kemanusiaan. ${ }^{15}$

c. Maria Montessori (1870-1952)

Ia dilahirkan di Italia (Roma) pada tahun 1870. Ia seorang dokter wanita dan menghentikan praktek kedokterannya pada tahun 1900. Kemudian terjun ke dunia pendidikan dengan mempelajari ilmu jiwa anak-anak (Kinder Psychologie).

Pada tahun 1907 Maria Montessori mendapat tawaran dari seorang pengusaha Roma untuk mendirikan sekolah bagi kanak-kanak. Oleh pengusaha kaya tersebut, Montessori diberi wewenang untuk mengelola sekolah tersebut dengan baik. Tawaran tersebut diterimanya dan Maria Montessori, akhirnya ia mendirikan "Casa Dei Bambini" yang berarti "rumah untuk merawat anak-anak". Montessori, memandang perkembangan anak usia dini sebagai suatu proses yang berkesinambungan. Pendidikan adalah sebagai aktivitas diri, dan mengarahkan anak pada pembentukan disiplin pribadi, kemandirian, dan pengarahan diri.

Demi memenuhi kebutuhan pendidikan anak tersebut, ia merancang sejumlah materi yang memungkinkan indra anak dapat berkembang dengan baik dan sempurna. Bila anak belajar tentang suara (melalui pendengaran), Montessori merancang suatu kumpulan kotak. Semua kotak tersebut sama, tetapi masing-masing kotak berisi bahan yang berbeda-beda, sehingga bila digoyangkan akan mengeluarkan suara yang tidak sama. Selanjutnya Montessori merancang alat belajar untuk meningkatkan fungsi penglihatan, penciuman, pengecap, dan perabaan, dengan cara sangat khas dan prinsip evaluasi diri.

Tak kalah menarik dari konsep teori pendidikan Montessori adalah pendidikan jasmani yang mengembangkan otot-otot, berkebun dan belajar tentang alam. Dengan pendidikan tentang alam, berkebun dan

${ }^{15}$ Patmonodewo, Pendidikan Anak Prasekolah ..., hlm. 6-8. 
mengembangkan otot-otot melalui olah raga diharapkan anak-anak akan memiliki pengalaman kehidupan dan memiliki fisik yang sehat dan kuat. Dengan demikian, anak akan dapat belajar dengan berbagai macam pengetahuan. Ia percaya bahwa pada usia sejak dini $02-06$ tahun adalah masa yang dianggap sangat "sensitif" untuk belajar mengenal membaca, dan menghitung. ${ }^{16}$

d. Abu Hamid Muhammad Al-Gazali (1058 M - 1111 M)

Al-Gazali dilahirkan di Kota Tos Khurasan (Persia). Sejak kecil al-Gazali menggemari ilmu pengetahuan, ia memiliki kecerdasan yang luar biasa. Sampai-sampai Imam Al-Juwaini menjuluki dengan sebutan "Bahr Mugriq" (lautan yang menenggelamkan). Kelebihan lain dari al-Gazali, adalah kemampuan ia terlibat dalam perdebatan (dialog) dengan beberapa ahli pikir, ulama dan orang-orang yang dianggap memiliki kelebihan ilmu darinya. Kemampuannya dalam berdebat ini telah menghantarkannya untuk diminta oleh penguasa (raja) ketika itu untuk membantu dalam mendidik dan mengajarkan ilmu agama kepada anak-anak Raja dan para prajuritnya di kota Baghdad (Irak sekarang), ini terjadi tahun $484 \mathrm{H} / 1091 \mathrm{M}$.

Keluasan dan kearifan Imam al-Gazali dalam menata kehidupan di dunia ini telah pula menghantarkannya ke jalan kehidupan sufistik. Ini ditandai dengan ajaranajarannya yang kemudian menjadi rujukan dan referensi bagi orang-orang yang ingin mendalami hakikat melalui ajaran tasawuf. Buku yang pertama kali disusun untuk mengetahui kehidupannya, beliau susun dalam "alMunqidz min al-Dalal". Di dalam buku ini berisi dan memuat gambaran kehidupan, terutama pada masa terjadi perubahan di dalam pandangannya tentang perihal hidup dan nilai-nilai. al-Gazali melukiskan proses internalisasi Iman di dalam jiwa, bagaimana hakikat-hakikat ilahiah dapat tersingkap bagi manusia. Bagaimana manusia dapat mencapai ma'rifat dengan penuh keyakinan tanpa melalui

\footnotetext{
${ }^{16}$ Soemiarti Patmonodewo, Pendidikan Anak Prasekolah, hlm. 9-10.
} 
proses berpikir dan berlogika, melainkan dengan jalan ilham dan pelacakan sufi. ${ }^{17}$

Al-Gazali dalam konsep pendidikan mengatakan bahwa pendidikan agama harus dimulai sejak usia dini. Sebab, dalam keadaan ini anak siap untuk menerima aqidah-aqidah agama semata-mata atas dasar iman, tanpa meminta dalil untuk menguatkannya, atau menuntut kepastian dan penjelasan. Oleh karena itu, dalam mengajarkan agama kepada anak-anak, hendaknya dimulai dengan menghafal kaidah-kaidah dan dasar-dasarnya. Setelah itu baru guru menjelaskan maknanya, sehingga mereka memahami, meyakini dan membenarkannya.

Anak usia dini menurut al-Gazali seharusnya dikenalkan dengan agama. Karena manusia dilahirkan telah membawa agama sebagaimana agama yang dibawa oleh kedua orang tuanya (ayah-ibu). Oleh karena itu seorang anak akan mengikuti agama kedua orang tua serta guru. Konsep ini menjadikan kedua orang tua sebagai pendidik yang utama menjadi kekuatan dalam diri anak, agar anak tumbuh dan kembang ke arah penyucian jiwa, berakhlak yang mulia bertakwa dan diharapkan menyebarkan keutamaan ke seluruh umat manusia.

Pemikiran Al-Gazali tentang konsep pendidikan, beliau tuangkan dalam kitabnya yang terkenal, yaitu "Ihya' 'Ulum al-Din". Karangan beliau ini hari ini menjadi rujukan dan landasan sebagian pemikir muslim yang mengangkat isu-isu pendidikan, terutama pendidikan keluarga.

e. Ki Hajar Dewantara (1889 - 1959)

Salah seorang tokoh yang berpengaruh dalam dunia pendidikan di Indonesia adalah Ki Hajar Dewantara. Beliau dilahirkan di daerah kauman, Yogyakarta, pada tanggal 2 Mei 1889 dan wafat pada tanggal 26 April 1959. Di Kota Pendidikan inilah, Ki Hajar Dewantara mengilhami lahirnya Perguruan Nasional Taman Siswa di Yogyakarta, pada tanggal 3 Juli 1922. Tahun pertama

17 Fathiyah Hasan Sulaiman, Alam Pikiran Al-Ghazali Mengenai Pendidikan dan Ilmu, (Bandung: Diponegoro, 1986), hlm. 19-22. 
berdirinya, Taman Siswa mulai membuka sekolah yang diberi nama "Taman Lare" atau "Taman Anak".

Dalam perkembangan selanjutnya, berdiri pula sekolah rendah dan sekolah lanjutan pertama di Perguruan Nasional Taman Siswa. Untuk kesesuaian dengan sifatsifat jiwa anak-anak sesuai dengan umurnya, maka setiap jenjang pendidikan diberi nama. "Taman Anak" untuk kelas I sampai dengan kelas III untuk usia anak $7-9$ tahun. "Taman Muda" untuk anak-anak muda untuk anak kelas IV sampai dengan VI berumur antara 10 - 13 tahun. Kemudian untuk kelas VII dan sekolah lanjutan pertama diperuntukkan bagi anak-anak dewasa diberi nama "Taman Dewasa".

Konsep Ki Hajar Dewantara tentang pendidikan beliau tuangkan melalui "Tri Sentra Pendidikan" yang dikembangkan di Perguruan Taman Siswa, yaitu sentra keluarga, sentra perguruan dan sentra masyarakat. Dalam konteks sentra keluarga, pendidikan keluarga telah melahirkan konsep "among", di mana konsep ini menuntut para orang tua untuk bersikap, yaitu: (a) ing ngarso sung tolodo, (b) ing madya mangun kasra, (c) tut wuri handayani.

Dalam konteks sentra keluarga, Ki Hajar Dewantara sangat peduli dalam memperhatikan, bahkan meminta para orang tua untuk mendidik anak-anak sejak usia dini (alam keluarga). Alam keluarga itu adalah suatu tempat yang sebaik-baiknya untuk melakukan pendidikan kesusilaan dan kesosialan. Sehingga boleh dikatakan, bahwa keluarga itu tempat pendidikan yang lebih sempurna sifat dan wujudnya dari pada tempat-tempat lainnya, guna untuk melangsungkan pendidikan ke arah kecerdasan budi pekerti (pembentukan watak individual) dan sebagai persediaan hidup kemasyarakatan. ${ }^{18}$

Pentingnya pendidikan keluarga bagi pertumbuhan dan perkembangan anak di kemukakan lebih lanjut oleh Ki Hajar Dewantara (1961) bahwa alam keluarga, adalah:

1) Alam pendidikan yang permulaan, pendidikan pertama kalinya bersifat pendidikan dari orang tua yang

${ }^{18}$ Dewantara, Ilmu Pendidikan ..., hlm. 374. 
berkedudukan sebagai guru (penuntut), sebagai pengajar dan sebagai pemimpin,

2) Di dalam keluarga itu anak-anak dididik,

3) Di dalam keluarga anak-anak berkesempatan mendidik diri sendiri, karena di dalam hidup keluarga itu mereka tidak berbeda kedudukannya,

4) Di dalam keluarga orang tua sebagai guru dan penuntun, sebagai pengajar, sebagai pemberi contoh dan teladan bagi anak-anak.

f. Engku Muhammad Syafe'i

Engku Muhammad Syafe'i lahir di Kalimantan Barat, tepatnya di daerah Natan, pada tahun 1895 dan ia berdarah Minang. Anak dari Mara Sutan dan Indung Khodijah. Setelah Ki Hajar Dewantara mendirikan perguruan Nasional Taman Siswa di Yogyakarta. Di wilayah Sumatera muncul seorang penggagas yang cerdas dan memiliki pemikiran progresif dari kaum terpelajar Sumatera, terutama Sumatera Barat. Dengan latar belakang pendidikan yang ditempuh selama di Jawa dan didukung latar belakang kehidupan keluarga yang memahami arti penting pendidikan dan perjuangan, maka di tangan Muhammad Syafe'i tahun 1926 lahirlah Indonesisch Nederlansche School (INS) Kayu Tanam, tepatnya pada tanggal 31 Oktober 1926.

Kehadiran INS Kayu Tanam, di bumi Sumatera sebagai lembaga pendidikan telah melahirkan harapan baru di kalangan masyarakat pribumi. Sesuai dengan citacitanya, sekolah berfungsi mengasah kecerdasan dan akal budi murid, bukan membentuk manusia lain dari dirinya sendiri. Tujuan pendidikan dari INS Kayu Tanam adalah melahirkan manusia yang kreatif, inovatif, intelektual, berakhlak mulia, mandiri, cerdas dan beretos kerja. Selanjutnya Engku Muhammad Syafe'i dalam Anfasa Moelok ${ }^{19}$ menyatakan bahwa:

"Mendidik dan membina siswa hendaknya senantiasa kreatif dalam mengembangkan bakat dan keilmuannya, mandiri, cerdas dan beretos kerja, berkemampuan

19 Anfasa Moeloek, Fasli Jalal \& Farid, Bahan Seminar ISN Kayu Tanam, (2006), hlm. 112. 
intelektual, berwawasan dan berbudaya, beriman, bertakwa serta berakhlak mulia dalam pengabdiannya kepada masyarakat".

Begitu bermakna dan dalamnya konsep pendidikan yang ditawarkan oleh Engku Muhammad Syafe'i, sehingga telah mencuri banyak perhatian para orang tua, terutama di wilayah bumi Minangkabau. Hanya beberapa tahun berdiri, keagungan konsep pendidikan yang dilakukan INS Kayu Tanam itu tersebar, terlebih dengan filosofisnya yang sangat terkenal yaitu "Alam ta Kambang jadi Guru". Pendidikan sebagai simbol kemajuan bangsa. Ucapan beliau sampai hari ini masih menjadi semangat pendorong bagi kemajuan pendidikan INS Kayu Tanam, yakni "pendidikan salah satu alat yang terbesar untuk kemajuan bangsa dan akhirat". ${ }^{20}$

Memaknai apa yang dikembangkan Engku Muhammad Syafe'i melalui pendidikan INS Kayu Tanam, sangat nyata sekali bahwa dalam kultur masyarakat Minangkabau senantiasa menjunjung tinggi tradisi budaya. Hampir sebagian besar konsep belajarnya, menyesuaikan tradisi masyarakat Minangkabau, yang kuat akan nilai-nilai agama dalam memegang akidah Islam. Engku Muhammad Syafe'i sangat meyakini melalui kekuatan sendi keagamaan (Islam), pendidikan akan melahirkan anakanak dan generasi yang berakhlak mulia sebagaimana konsep dari tujuan pendidikannya.

\section{Implikasi Teori-teori Pendidikan Keluarga pada Anak Usia Dini}

Undang-undang sistem pendidikan nasional nomor 20 Tahun 2003, Bab I Pasal 1 ayat 13, menyebutkan bahwa "pendidikan informal adalah jalur pendidikan keluarga dan lingkungan." Selanjutnya pasal-pasal 27 ayat 1, mempertegas bahwa "kegiatan pendidikan informal yang dilakukan oleh keluarga dan lingkungan berbentuk kegiatan belajar secara mandiri”. Berdasarkan Undang-undang di atas, secara konstitusional keberadaan jalur pendidikan secara informal (pendidikan di dalam keluarga) menjadi kekuatan hukum yang legal formal. Secara hak-hak kewarganegaraan sudah semestinya dilaksanakan oleh semua

${ }^{20}$ Moeloek \& Farid, Bahan Seminar...., hlm. 113-114. 
orang tua. Apalagi ketentuan-ketentuan secara teknis operasionalisasi memiliki ketetapan yuridis formal.

Dalam prakteknya, pendidikan keluarga belum sepenuhnya dilaksanakan oleh para orang tua yang memiliki anak-anak di rumah. Banyak faktor mengapa kemudian konsep pendidikan di dalam keluarga yang seharusnya telah diberikan oleh orang tua, belum optimal dipraktikkan dalam kehidupan keseharian para orang tua dalam mendidik anaknya di rumah. Menurut pemikiran penulis faktor penyebab masalah tersebut adalah:

1. Kurangnya pengetahuan dan pemahaman para orang tua tentang kedudukan peran dan fungsi serta tanggung jawab para orang tua dalam hal pendidikan anak-anak di rumah. Kekurangan pengetahuan dan pemahaman bisa disebabkan tingkat pendidikan para orang tua yang rendah, akibat ketidakmampuan dalam penyelesaian sekolah. Hal ini dapat kita jumpai terhadap banyaknya anak-anak putus sekolah, meningkatnya angka pengangguran yang tidak terdidik, serta lemahnya persaingan dalam ranah tenaga kerja.

2. Lemahnya peran sosial budaya masyarakat dalam membangun kesadaran akan pentingnya pendidikan keluarga. Keluarga sering kali mengabaikan nilai-nilai edukasi di dalam ranah rumah tangga, dengan membiarkan anak-anak bermain dan bergaul tanpa kontrol, kurangnya perhatian tatkala ia sedang berkomunikasi dengan sesamanya. Sikap apatis sebagian besar para orang tua terhadap tata krama pergaulan anak-anak di lingkungan bermain.

3. Kuatnya desakan dan tarikan pergulatan ekonomi para orang tua dalam memenuhi tuntutan dan kebutuhan keluarga. Sehingga mengabaikan peran-peran sebagai fungsi dan tugas orang tua bahkan ada yang tanpa disadari, akibat tuntutan kebutuhan ekonomi mereka (ayah dan ibu) lupa akan tanggung jawabnya sebagai orang tua. Mereka tinggalkan anak-anak tanpa perhatian, bimbingan dan pendidikan sebagaimana mestinya. Dalam banyak kasus, di depan mata kita sendiri menyaksikan banyak anak tumbuh tanpa perhatian orang tua. Bahkan dengan menghela nafas dalam-dalam kita menyaksikan anak-anak telah dijadikan alat (objek) komersialisasi bagi orang tua untuk mendapatkan penghasilan (uang) untuk memenuhi kebutuhan keluarga. 
4. Kemajuan arus teknologi informasi yang meluas turut pula mempengaruhi cara berpikir dan bertindak para orang tua. Misalnya perilaku instan dengan memberi fasilitas media yang tidak mendidik, membiarkan mengakses berbagai informasi tidak mendidik, baik melalui tayangan media televisi dan pengawasan (proteksi) yang tidak terkontrol, akibat ketidakpedulian para orang tua.

Harus diakui galaunya para stakeholder di negeri ini menyaksikan banyaknya anak-anak tidak memperoleh perhatian yang besar dari para orang tua. Akhirnya, Pemerintah melalui lembaga dan institusi yang berwenang telah mencanangkan gerakan "Pendidikan Anak Usia Dini", yang terdapat di dalam Undang-Undang Sistem Pendidikan Nasional (Sisdiknas) pada bagian ke tujuh pasal 27 ayat 5, menyebutkan "Pendidikan Anak Usia Dini pada jalur informal berbentuk pendidikan keluarga atau pendidikan yang diselenggarakan oleh lingkungan". Ayat 1 berbunyi "Pendidikan Anak Usia Dini diselenggarakan sebelum jenjang pendidikan dasar".

Kenyataan di atas, mempertegas kita para orang tua, bahwa pendidikan anak-anak hendaknya sedari awal telah diberikan oleh para orang tua. Bila memungkinkan pendidikan anak-anak tersebut bisa diberikan di saat seorang ibu mengandung sang jabang bayi. Begitu urgensinya pendidikan keluarga telah mengisyaratkan kepada para orang tua untuk sungguh-sungguh dalam menjadikan pendidikan keluarga sebagai fondasi yang kuat. Proses pendidikan anak sangat berguna untuk mengembangkan potensi yang dimiliki mereka. Sehingga anak menjadi sosok yang berkepribadian cerdas, sempurna dan unggul dalam merajut masa depan anak yang didambakan oleh semua para orang tua, masyarakat dan negara.

\section{Kesimpulan}

Keluarga adalah lembaga yang utama dan pertama bagi proses awal pendidikan anak-anak untuk mengembangkan potensi yang dimiliki seorang anak ke arah pengembangan kepribadian diri yang positif dan baik. Orang tua (ayah dan ibu) memiliki tanggung jawab yang besar dalam mendidik anak-anak dalam keluarga. Fungsi-fungsi dan peran orang tua tidak hanya sekedar memenuhi kebutuhan fisik anak berupa kebutuhan makan dan minum, pakaian, tempat tinggal tapi juga tanggung jawab orang tua jauh 
lebih penting dari itu adalah memberi perhatian, bimbingan, arahan, motivasi, dan pendidikan, serta penanaman nilai.

Besarnya tanggung jawab orang tua (ayah dan ibu) mendidik anak dalam lingkungan keluarga di dukung pula dengan teori-teori pendidikan yang dikemukakan oleh para filosof dan pemikir yang mencurahkan hidupnya untuk dunia pendidikan. Seperti Comenius, J.H. Pestolozzi, F. Frobel, Maria Montessori, AlGazali, Ki Hajar Dewantara dan Engku Muhammad Syafe'i. Konsep yang ditawarkan melalui teori-teori tersebut telah menjadi rujukan dan referensi bagi perkembangan dan pengembangan pendidikan anak-anak terutama Pendidikan Anak Usia Dini (PAUD) di Indonesia.

\section{Kepustakaan}

Abdullah, M. Imron, Pendidikan Keluarga Bagi Anak, (Cirebon: Lektur, 2003).

Soenarjo, A., al-Qur'an dan Terjemahnya, (Jakarta: Teraju, 1989).

Berns, Roberta M., Child, Family, School, Community Socialization and Support, (United State: Thomson Corporation, 2007).

Hasan, Fathiyah Sulaiman, Alam Pikiran Al-Gazali Mengenai Pendidikan dan Ilmu, (Bandung: Diponegoro, 1986).

Jalal, Fasli \& Farid Anfasa Moeloek, Bahan Seminar ISN Kayu Tanam, (2006).

Dewantara, Ki Hajar, Ilmu Pendidikan, (Yogyakarta: Taman Siswa, 1961).

Langgulung, Hasan, Manusia dan Pendidikan, (Jakarta: Pustaka al-Husna, 1986).

Mansur, Pendidikan Anak Usia Dini dalam Islam, (Yogyakarta: Pustaka Pelajar, 2005).

Patmonodewo, Soemiarti, Pendidikan Anak Prasekolah, (Jakarta: Rineka Cipta, 2003).

Sadullah, Uyoh, Pengantar Filsafat Pendidikan, (Bandung: Alfabeta, 2007).

Soemarjan, Selo, Sosiologi Suatu Pengantar, (Yogyakarta: Gajah Mada Press, 1962).

Undang-Undang Nomor 20 Tahun 2003 tentang Sistem Pendidikan Nasional. 
